\title{
Effect of storage duration and temperature on external and internal egg quality characteristics of fertile and non-fertile eggs
}

${ }^{1}$ Oshibanjo, D. O., ${ }^{2}$ Sati, N. M, ${ }^{2}$ Emennaa, P. E., ${ }^{1}$ Okpanchi, U., ${ }^{2}$ Nwamo, A. C., ${ }^{2}$ Mbuka, J. J., ${ }^{2}$ Njam R. L., ${ }^{1}$ Mwadkon, P. B., ${ }^{2}$ Ejidare, D. A., ${ }^{1}$ Kaze, A. D. and ${ }^{1}$ Ene, P. N.

${ }^{* 1}$ Department of Animal Production, University of Jos, Jos Plateau State Nigeria

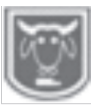

${ }^{2}$ Poultry Division, National Veterinary Research Institute,

Vom Jos Plateau State Nigeria

Corresponding author: oshibanjoo@unijos.edu.ng; +2348055438564

\section{Abstract}

Due to consumer attitude and perception on fertile and non-fertile eggs from pervious study, this study aimed to evaluate the interaction effect of temperature and storage duration on fertile and non-fertile eggs on egg quality characteristics. A total of 600 eggs were obtained from Lohmann brown hens, at 44 weeks. Roasters were removed from the hen that laid nonfertile eggs. Eggs collection started after 30 days of roaster withdrawal. Eggs were stored for 5, 10, 15 and 20 days respectively under room temperature (ambient) $27-31^{\circ} \mathrm{C}$ and refrigeration $\left(10^{\circ} \mathrm{C}\right)$ temperature in a $2 \times 5$ factorial arrangement of a completely randomized design. Egg quality characteristics and sensory evaluation were assessed using standard procedures. Data were analysed using ANOVA at $\alpha_{0.05}$. The yolk weight, yolk height, yolk diameter, yolk ratio and yolk index showed significant differences $(p<0.05)$ with storage days. Yolk colour of fertile egg stored in refrigerator at day 15 was significantly higher than other storage days. The albumen weight, albumen height, albumen length, albumen ratio and Haugh unit shows significant difference $(p<0.05)$. Overall acceptability of fertile eggs was recorded to be the highest at day 10 of storage at room temperature. In conclusion, interaction between storage days and temperature revealed that fertile eggs can be stored in refrigerator and at room for 10 days without adverse effect on the eggs quality.

Keywords: Storage temperature and storage duration, fertile egg, non-fertile egg and egg quality characteristics

\section{L'Effet de la durée et de la température de stockage sur les caractéristiques externes et internes de la qualité des oufs fertiles et non fertiles}

\section{Résumé}

En raison de l'attitude des consommateurs et de la perception sur les oufs fertiles et non fertiles provenant d'études perméables, cette étude visait à évaluer l'effet d'interaction de la température et de la durée de stockage sur les oufs fertiles et non fertiles sur les caractéristiques de qualité des æufs. Un total de 600 oeufs ont été obtenus à partir de poules brunes Lohmann, à 44 semaines. Les torréfacteurs ont été retirés de la poule qui pondait des oufs non fertiles. La collecte des æufs a commencé après 30 jours de retrait de la rôtissoire. Les æufs ont été conservés pendant 5, 10, 15 et 20 jours respectivement sous température ambiante (ambiante) 27 -310C et température de réfrigération (100C) dans un arrangement factorial de $2 \times 5$ d'une conception complètement randomisée. Les caractéristiques de qualité des oufs et l'évaluation sensorielle ont été évaluées à l'aide de procédures normalisées. Les données ont été analysées à l'aide d'ANOVA à $\alpha 0,05$. Le poids du jaune, la taille du jaune, le diamètre du jaune, le rapport jaune et l'indice du jaune ont montré des différences significatives $(p<0,05)$ avec les jours de stockage. La couleur jaune des cufs 


\section{Effect of storage duration and temperature on external and internal egg quality}

fertiles conservés au réfrigérateur au jour 15 était significativement plus élevée que les autres jours d'entreposage. Le poids d'albumen, la hauteur d'albumen, la longueur d'albumen, le rapport d'albumen et l'unité de Haugh montre la différence significative $(p<0,05)$. Dans l'ensemble, l'acceptabilité des œufs fertiles a été enregistrée comme la plus élevée au jour 10 de l'entreposage à température ambiante. En conclusion, l'interaction entre les jours d'entreposage et la température a révélé que les oufs fertiles peuvent être conservés au réfrigérateur et à la pièce pendant 10 jours sans effet négatif sur la qualité des oufs.

Mots-clés: Température de stockage et durée de stockage, œuf fertile, caractéristiques non fertiles de la qualité des œufs et des œufs

\section{Introduction}

The high demand for poultry products and the high income generated from poultry farming have driven a large number of producers and investors into the poultry sector. In Nigeria, harvest of poultry produce is high and poor storage conditions may result in deterioration in quality and losses as a result of spoilage and wastage (Raji et al., 2009). Indisputably, eggs are one of nature's most perfectly balanced foods consumed mainly as a source of protein having the highest protein quality than any other food (NECC, 2014). Eggs are palatable and highly affordable and may be obtained from a large variety of birds both domesticated and wild. Chicken eggs are most widely produced and consumed because chickens have short generation and gestation interval, high prolificacy, fast growth rate and are easy to raise (Fasina et al., 2012; Kabir et al., 2013). Stadelman (1986) defined egg quality as the characteristics of an egg both internally and externally that would affect the consumer's acceptability. According to Jibir et al. (2012), consumers show preference to external quality of eggs such as egg cleanliness, colour, texture and shape, egg weight and shell quality. They reported that brown eggs are most preferred in Nigeria. Research have shown that brown eggs have higher shell strength compared to white eggs and a higher weight as a result of more shell and albumen but less yolk (Scotts and Silversides, 2000). Reduction in egg quality is associated with loss in shell quality, thinning and watery albumen, yolk enlargement and flattening (due to proteolysis and loss of carbondioxide) and movement of bacteria into egg shell leading to rotting of eggs (Raji et al., 2009). Obi and Igbokwe (2009) observed the presence of pathogenic and spoilage microorganisms in eggs which tend to increase with storage time and poor storage conditions. Among the numerous methods of egg storage, refrigeration is still reported to be the best (as long as power supply remains favourable) while oiling gives better results compared to eggs stored in open crates or bowls at room temperature (Okeudo et al., 2005; Raji et al., 2009). Okeudo et al. (2005) also noted that packaging in polyethene bags may be somewhat similar to oiling.

Internal egg quality involves the functional, aesthetic and microbial properties of egg yolk and albumen (Leeson, 2006). According to the Food and Health Organization (FAO) 2003, the most accurate test for internal quality is the breakout method in which the eggs are opened on a flat glass surface to compare the appearance of the yolk and albumen. Candling method can also be used to detect eggs that are fertile. Albumen quality can be measured correctly using the Haugh unit or more correctly using the height of the thick albumen alone (Scotts and Silversides, 2000). The higher the value of the Haugh unit, the firmer the egg and the higher the quality, the value decreases as age increases (USDA, 2011). Albumen pH can also be used as a test for internal egg quality. Yolk quality can be measured using 
the yolk index (which is gotten by dividing the yolk height by its width) and the Yolk $\mathrm{pH}$. Quality eggs have firm yolks that stand upright with pleasant mild egg odour and flavor surrounded by a large amount of upstanding thick white with only a small amount of thin white (FAO, 2003). The main degradation factors for eggs are storage days (time), (Bell 1996), temperature, humidity, air movement, and handling (Stadelman 1995; Samli et al., 2005). Internal quality deterioration of eggs can be retarded significantly by maintaining storage temperature, because quality deterioration occurs faster at high temperatures than at refrigerated temperatures during storage (Joseph and Ogundele; 1996Zeidler, 2002) Egg storage influences the rate at which eggs undergo physical and biochemical changes that lead to the reduction in egg quality thus influencing its nutritional composition and acceptability for consumption and other uses (Scotts and Silversides, 2000; Okeudo et al, 2005; Raji, 2009; Mohammed, 2011; Fasina et al., 2012) According to Stadelman (1986), egg quality refers to the characteristics of an egg that will affect its acceptability to the consumer. It then becomes necessary to properly store eggs in order to maintain its quality and also to derive maximum utility from utilization of eggs. Therefore, this study aims at identifying a suitable method that will significantly reduce the rate at which biological and physiochemical changes occur within the egg with respect to storage and temperature.

\section{Materials and methods Experimental site}

This study was carried out at the Animal Products and Processing laboratory, Department of Animal Production, University of Jos, Plateau State. It is situated at the extreme North of the State and located between latitude $9^{\circ}$ E55' North of the Greenwich meridian and longitude $8^{0}$ E54' East of the Equator (Haruna et al., 2007).

\section{Collection of experimental material}

A total of 600 fertile and non-fertile eggs were collected from Poultry Division of National Veterinary Research Institute, Plateau State (NVRI) in four successive weeks were used for this study. The eggs were obtained from Lohmann brown hens, at 44 weeks of age and were used to evaluate egg quality characteristics. Roasters were removed from the hen that laid non-fertile eggs. Eggs collection started after 30 days of roaster withdrawal. Out of the 300 eggs in each of the storage methods, 20 were randomly picked after the following storage days $(5,10,15$ and 20, respectively) for determination of egg quality characteristics and the remaining eggs (how many eggs) were used at every storage day for sensory evaluation.

\section{Sampling and storing of egg}

Immediately after egg collection, eggs were labelled and numbered using a non-harmful permanent marker. Eggs were weighed according to date of collection using sensitive scale. To study the effect of storage days on egg quality parameters, eggs were stored in refrigerator at $10^{\circ} \mathrm{C}$, ambient (room) temperature of $28-31^{\circ} \mathrm{C}$ for $5,10,15$ and 20 days respectively and humidity was $55-60 \%$ for all treatments. The stored eggs were at each corresponding storage days and temperature.

\section{Evaluation of egg quality}

External quality characteristics of eggs were taken. This include Egg length $(\mathrm{cm})$ measured with a digital vernier caliper, Egg weight measured using a sensitive scale by weighing the eggs individually (taken as the weight of the oven dried egg shell). The shell thickness measured with a micrometer screw gauge which is the thickness of the dried egg shell (the mean of the three pointsnarrow, broad and middle). After this process, eggs were carefully cracked open 


\section{Effect of storage duration and temperature on external and internal egg quality}

with a spoon in a flat plate on a table without breaking the vitelline membrane, in order to measure the internal quality characteristics. The parameters were then taken immediately. The internal parameters measured were:

Yolk Width: Measured as the widest horizontal circumference with a vernier caliper.

Yolk Height: Measured as the height of the yolk at mid-point with a tripod micrometer.

Albumen Height: Measured as the height of the thick albumen.

Albumen Width: Measured as the widest horizontal circumference.

Albumen Weight: Calculated as the difference in weight of the egg and weight of the yolk plus shell.

Yolk Index: Calculated as the yolk height divided by the yolk width $(\mathrm{cm})$.

Albumen Index: Calculated as the ratio of the albumen height to egg width.

Haugh Unit was determined using the formula below:

$\mathrm{HU}=100 \log \left(\mathrm{H}+7.5-1.7 \mathrm{~W}^{\wedge} 0.35\right)$

Where $\mathrm{HU}=$ Haugh unit

$\mathrm{H}=$ Height of the thick albumen $(\mathrm{mm})$

$\mathrm{W}=$ Egg weight (grams)

\section{Sensoryevaluation}

At every storage day, eggs from each treatment taken were sampled for sensory evaluation. A total of 20 trained individuals (male and female) aged between 22-35 years from Department of Animal Production University of Jos, Plateau State were employed to assess the coded egg samples. Equal bite size from each treatment was coded, replicated thrice and served for evaluation by the trainees on a 9point hedonic scale for colour, aroma, odour, taste, texture and overall acceptability. The eggs were boil in tap water at $100^{\circ} \mathrm{C}$ and simmer for 20 minutes. After being allowed to cool for 30 minutes under a fan, eggs were shelled and presented to the trained 20-man panelist

Table 1: Interaction effect of storage days and temperature differences on external characteristics of fertile and non-fertile egg

\begin{tabular}{|c|c|c|c|c|c|c|}
\hline \multirow[b]{2}{*}{ Parameter } & \multirow[b]{2}{*}{ Days } & \multicolumn{2}{|c|}{ Fertile Egg } & \multicolumn{2}{|c|}{ Non-Fertile Egg } & \multirow[b]{2}{*}{ SEM } \\
\hline & & $\begin{array}{c}\text { Room } \\
\text { Temperature }\end{array}$ & $\begin{array}{l}\text { Refrigerator } \\
\text { Temperature }\end{array}$ & $\begin{array}{c}\text { Room } \\
\text { Temperature }\end{array}$ & $\begin{array}{l}\text { Refrigerator } \\
\text { Temperature }\end{array}$ & \\
\hline \multirow[t]{6}{*}{ Egg weight } & 0 & $63.40^{\mathrm{bi}}$ & $62.60^{\mathrm{bi}}$ & $60.40^{\mathrm{bi}}$ & $64.80^{\mathrm{bi}}$ & 0.74 \\
\hline & 5 & $60.80^{\mathrm{bj}}$ & $63.10^{\mathrm{bij}}$ & $64.90^{\mathrm{bij}}$ & $68.00^{\mathrm{bi}}$ & 0.86 \\
\hline & 10 & $76.60^{\mathrm{aj}}$ & $77.60^{a j}$ & $78.40^{\text {aij }}$ & $84.00^{\mathrm{ai}}$ & 0.95 \\
\hline & 15 & $59.80^{\mathrm{bi}}$ & $62.70^{\mathrm{bi}}$ & $62.50^{\mathrm{bi}}$ & $65.00^{\mathrm{bi}}$ & 0.84 \\
\hline & 20 & $75.30^{\text {ai }}$ & $77.60^{\text {ai }}$ & $60.30^{\mathrm{bj}}$ & $64.40^{\mathrm{bj}}$ & 1.40 \\
\hline & SEM & 1.27 & 1.27 & 1.14 & 1.26 & \\
\hline \multirow[t]{6}{*}{ Egg length } & 0 & $56.40^{\text {ai }}$ & $56.40^{\mathrm{bi}}$ & $56.10^{\mathrm{bi}}$ & $57.30^{\text {ai }}$ & 0.37 \\
\hline & 5 & $56.40^{\mathrm{aj}}$ & $56.60^{\mathrm{bj}}$ & $62.70^{\text {ai }}$ & $59.00^{\mathrm{aij}}$ & 0.69 \\
\hline & 10 & $56.00^{\mathrm{aj}}$ & $64.00^{\mathrm{bi}}$ & $57.50^{\mathrm{bj}}$ & $60.00^{\mathrm{aj}}$ & 1.00 \\
\hline & 15 & $57.60^{\text {ai }}$ & $57.00^{\mathrm{bi}}$ & $57.40^{\text {bi }}$ & $56.20^{\text {ai }}$ & 0.75 \\
\hline & 20 & $57.40^{\text {ai }}$ & $57.80^{\mathrm{bi}}$ & $56.00^{\mathrm{bi}}$ & $57.50^{\text {ai }}$ & 0.27 \\
\hline & SEM & 0.45 & 0.82 & 0.57 & 0.53 & \\
\hline \multirow[t]{6}{*}{ Egg width } & 0 & 44.40 & 43.90 & 43.80 & 44.70 & 0.21 \\
\hline & 5 & 46.10 & 44.10 & 44.20 & 44.80 & 0.63 \\
\hline & 10 & 45.60 & 45.90 & 44.30 & 45.90 & 0.22 \\
\hline & 15 & 43.20 & 44.00 & 43.00 & 44.00 & 0.49 \\
\hline & 20 & 45.50 & 46.30 & 46.20 & 45.40 & 0.37 \\
\hline & SEM & 0.62 & 0.25 & 0.25 & 0.31 & \\
\hline
\end{tabular}


Table 2: Interaction effect of storage days and temperature differences on internal characteristics of fertile and non- fertile egg yolk

\begin{tabular}{|c|c|c|c|c|c|c|}
\hline \multirow[b]{2}{*}{ Parameter } & \multirow[b]{2}{*}{ Days } & \multicolumn{2}{|c|}{ Fertile Egg } & \multicolumn{2}{|c|}{ Non-Fertile Egg } & \multirow[b]{2}{*}{ SEM } \\
\hline & & $\begin{array}{c}\text { Room } \\
\text { Temperature }\end{array}$ & $\begin{array}{l}\text { Refrigerator } \\
\text { Temperature }\end{array}$ & $\begin{array}{c}\text { Room } \\
\text { Temperature }\end{array}$ & $\begin{array}{l}\text { Refrigerator } \\
\text { Temperature }\end{array}$ & \\
\hline \multirow[t]{6}{*}{ Yolk weight } & 0 & $15.40^{\mathrm{ai}}$ & $14.80^{\mathrm{ci}}$ & $16.50^{\mathrm{bi}}$ & $15.50^{\mathrm{ai}}$ & 0.24 \\
\hline & 5 & $16.00^{\text {ai }}$ & $16.00^{\text {bci }}$ & $16.60^{\mathrm{bi}}$ & $17.40^{\mathrm{ai}}$ & 0.22 \\
\hline & 10 & $16.90^{\mathrm{ai}}$ & $25.70^{\mathrm{ai}}$ & $24.30^{\mathrm{ai}}$ & $18.00^{\mathrm{aj}}$ & 0.99 \\
\hline & 15 & $17.50^{\text {aj }}$ & $17.70^{\mathrm{bci}}$ & $17.60^{\mathrm{bi}}$ & $17.60^{\mathrm{ai}}$ & 0.23 \\
\hline & 20 & $18.40^{\mathrm{ai}}$ & $18.30^{\mathrm{bi}}$ & $17.00^{\mathrm{bi}}$ & $18.30^{\mathrm{ai}}$ & 0.22 \\
\hline & SEM & 0.22 & 0.70 & 0.68 & 0.18 & \\
\hline \multirow[t]{6}{*}{ Yolk height } & 0 & $15.20^{\mathrm{bci}}$ & $14.40^{\mathrm{ki}}$ & $15.50^{\mathrm{ai}}$ & $15.20^{\mathrm{bi}}$ & 0.27 \\
\hline & 5 & $13.30^{\mathrm{cdj}}$ & $13.90^{\mathrm{cj}}$ & $14.50^{\mathrm{abj}}$ & $17.50^{\mathrm{ai}}$ & 0.39 \\
\hline & 10 & $13.00^{\mathrm{dk}}$ & $15.80^{\mathrm{bcj}}$ & $14.10^{\mathrm{abjk}}$ & $17.90^{\mathrm{ai}}$ & 0.41 \\
\hline & 15 & $16.50^{\mathrm{abi}}$ & $18.40^{\mathrm{ai}}$ & $12.80^{\mathrm{bcj}}$ & $10.90^{\mathrm{cj}}$ & 0.56 \\
\hline & 20 & $17.90^{\mathrm{ai}}$ & $17.00^{\mathrm{abi}}$ & $12.20^{\mathrm{cj}}$ & $11.90^{\mathrm{cj}}$ & 0.47 \\
\hline & SEM & 0.36 & 0.37 & 0.24 & 0.48 & \\
\hline \multirow[t]{6}{*}{ Yolk diameter } & 0 & $39.00^{\mathrm{abi}}$ & $37.40^{\mathrm{bi}}$ & $37.20^{\mathrm{ci}}$ & $38.10^{\mathrm{ci}}$ & 0.41 \\
\hline & 5 & $40.60^{\mathrm{ai}}$ & $39.70^{\mathrm{abi}}$ & $40.60^{\mathrm{bi}}$ & $40.80^{\mathrm{bci}}$ & 0.39 \\
\hline & 10 & $41.30^{\mathrm{ai}}$ & $40.20^{\mathrm{abi}}$ & $41.30^{\mathrm{bi}}$ & $40.30^{\text {bci }}$ & 0.32 \\
\hline & 15 & $37.10^{\mathrm{bk}}$ & $39.60^{\mathrm{abjk}}$ & $43.40^{\mathrm{abi}}$ & $42.20^{\mathrm{abij}}$ & 0.58 \\
\hline & 20 & $41.80^{\mathrm{aij}}$ & $41.50^{\mathrm{ab}}$ & $44.50^{\mathrm{ai}}$ & $44.40^{\mathrm{ai}}$ & 0.33 \\
\hline & SEM & 0.40 & 0.40 & 0.50 & 0.40 & \\
\hline \multirow[t]{6}{*}{ Yolk colour } & 0 & 8.70 & 8.80 & 8.80 & 8.70 & 0.07 \\
\hline & 5 & 10.50 & 10.10 & 10.40 & 10.20 & 0.15 \\
\hline & 10 & 9.30 & 10.30 & 9.50 & 10.30 & 0.17 \\
\hline & 15 & 10.50 & 10.90 & 10.00 & 10.40 & 0.10 \\
\hline & 20 & 10.60 & 10.00 & 10.20 & 10.40 & 0.15 \\
\hline & SEM & 0.16 & 0.16 & 0.15 & 0.12 & \\
\hline \multirow[t]{6}{*}{ Yolk ratio } & 0 & $24.39^{\mathrm{abi}}$ & $23.71^{\mathrm{bi}}$ & $27.39^{\mathrm{abi}}$ & $24.15^{\mathrm{abi}}$ & 0.50 \\
\hline & 5 & $26.53^{\mathrm{abi}}$ & $25.44^{\mathrm{bi}}$ & $25.62^{\mathrm{bi}}$ & $25.70^{\mathrm{abi}}$ & 0.40 \\
\hline & 10 & $22.97^{\mathrm{bj}}$ & $33.62^{\mathrm{ai}}$ & $31.26^{\mathrm{ai}}$ & $21.48^{\mathrm{bj}}$ & 1.41 \\
\hline & 15 & $28.45^{\mathrm{ai}}$ & $28.30^{\mathrm{bi}}$ & $28.34^{\mathrm{abi}}$ & $27.19^{\mathrm{ai}}$ & 0.45 \\
\hline & 20 & $24.45^{\mathrm{abij}}$ & $23.62^{\mathrm{bj}}$ & $28.42^{\mathrm{abij}}$ & $28.55^{\mathrm{ai}}$ & 0.52 \\
\hline & SEM & 0.44 & 0.85 & 0.84 & 0.46 & \\
\hline \multirow[t]{6}{*}{ Yolk index } & 0 & $39.04^{\mathrm{ai}}$ & $38.67^{\mathrm{bi}}$ & $41.78^{\mathrm{ai}}$ & $40.02^{\mathrm{ai}}$ & 0.81 \\
\hline & 5 & $32.87^{\mathrm{bj}}$ & $35.41^{\mathrm{bj}}$ & $35.83^{\mathrm{bj}}$ & $42.92^{\mathrm{ai}}$ & 1.02 \\
\hline & 10 & $31.65^{\mathrm{bk}}$ & $39.22^{\mathrm{bij}}$ & $34.23^{b c}$ & $44.38^{\mathrm{ai}}$ & 1.03 \\
\hline & 15 & $44.76^{\mathrm{ai}}$ & $46.43^{\mathrm{ai}}$ & $29.77^{\text {cdjkj }}$ & $25.89^{\mathrm{bj}}$ & 1.67 \\
\hline & 20 & $42.85^{\mathrm{ai}}$ & $40.99^{\mathrm{abi}}$ & $27.49^{\mathrm{dj}}$ & $26.79^{\mathrm{bj}}$ & 1.27 \\
\hline & SEM & 1.02 & 0.91 & 0.89 & 1.30 & \\
\hline
\end{tabular}

who judged using a 9-point hedonic scale from 9 (extremely like) to 1 (extremely dislike). Cold distilled water was provided for panelists to rinse their mouth in between samples.

\section{Experimental design}

A $2 \times 2 \times 5$ factorial arrangement in a Completely Randomized Design was used for this study.

2 storage temperature, 2 egg types (Fertile and non-fertile eggs) and 5 storage duration. Statistical analysis

Data collected were analyzed using Assistat version 7.7. Statistical variations were observed and means were separated using Tukeys' HSD. 


\section{Effect of storage duration and temperature on external and internal egg quality}

\section{Results}

The interaction effect of storage days and temperature differences on external characteristics of eggs is shown in Table 1. The egg weight recorded on day 10 was significantly higher $(p<0.05)$ than in all other storage days. Similar result was obtained for egg length. However, no significant difference $(p>0.05)$ was observed in the egg width for all the storage days $0,5,10,15$ and 20 under ambient and refrigerator temperatures. The interaction effect of storage days and temperature differences on internal characteristics of fertile and non-fertile egg yolk is presented in Table 2. The yolk weight and yolk colour were not significantly different $(\mathrm{p}>0.05)$ with storage days both at room and refrigerator temperatures. The yolk weight, height, diameter, ratio and yolk index showed significant differences $(\mathrm{p}<0.05)$ in all the storage days. Yolk weight was significantly higher in fertile egg at refrigerator temperature on day 10 with least weight fertile egg at refrigerator temperature on day 0 . Yolk height was significantly higher in fertile eggs stored in refrigerator temperature on day 15 , while the least was recorded at day 15 of nonfertile egg at refrigerator. Yolk colour of fertile egg stored in refrigerator at day 15 was significantly higher than all the storage days $\backslash$

The interaction effect of storage days and temperature differences on fertile and nonfertile egg albumen is presented in Table 3. The Albumen weight, Albumen height, Albumen length and Albumen ratio showed significant differences $(\mathrm{p}<0.05)$. Albumen weight was significantly higher at day 20 with the least at day 0 of non-fertile eggs in refrigerator. Albumen height was recorded to be the highest at day 0 of fertile eggs under room temperature, while the lowest was observed at day 20 of non-fertile eggs under room temperature. Highest albumen length was obtained for non-fertile eggs in refrigerator at day 15 , with lowest at day 0 for fertile egg in refrigerator.

Table 4 shows the Interaction effect of storage days and temperature differences on fertile and non-fertile albumen internal characteristics. Significant differences $(\mathrm{p}<0.05)$ were observed in Yolk: Albumen, Haugh unit and Egg surface area while the Shape index showed no significant difference $(p>0.05)$.

The interaction effect of storage days and temperature differences on sensory evaluation of fertile and non-fertile eggs is presented in Table 5. The colour and texture was observed to be statistically significant $(\mathrm{p}<0.05)$ in all the storage days $0,5,10,15$ and 20 for both fertile and non-fertile eggs stored in room and refrigerator temperature. The colour of non-fertile eggs was recorded to be the highest at day 10 of refrigerator temperature while the texture of fertile eggs was recorded to be the highest at day 10 and 15 of room temperature. Overall acceptability of fertile eggs was recorded to be the highest at day 10 of storage at room temperature.

\section{Discussion}

It was observed that storage days and temperature increased the value of yolk diameter. This increase in yolk diameter observed in this study could be due to decrease in the strength of vitelline membrane. When eggs are stored under room temperature for long periods, the strength of vitelline membrane breaks and makes the yolk spread into the albumen. These results are in agreement with Kirunda and McKee (2000) who observed that vitelline membrane strength (VMS) decreases during storage and makes the yolk more susceptible to breakage, as a result, water slowly enters into the yolk from the albumen, so this creates a mottled appearance in yolk, and the yolk becomes flattened. The yolk diameter values were higher in room temperature, because at a 
Oshibanjo, Sati, Emennaa, Okpanchi, Nwamo, Mbuka, Njam, Mwadkon, Ejidare, Kaze. and Ene

Table 3: Interaction effect of storage days and temperature difference on fertile and non-fertile egg albumen

\begin{tabular}{|c|c|c|c|c|c|c|}
\hline \multirow[b]{2}{*}{ Parameter } & \multirow[b]{2}{*}{ Days } & \multicolumn{2}{|c|}{ Fertile Egg } & \multicolumn{2}{|c|}{ Non-Fertile Egg } & \multirow[b]{2}{*}{ SEM } \\
\hline & & $\begin{array}{c}\text { Room } \\
\text { Temperature }\end{array}$ & $\begin{array}{l}\text { Refrigerator } \\
\text { Temperature }\end{array}$ & $\begin{array}{c}\text { Room } \\
\text { Temperature }\end{array}$ & $\begin{array}{l}\text { Refrigerator } \\
\text { Temperature }\end{array}$ & \\
\hline \multirow[t]{6}{*}{ Albumen weight } & 0 & $38.70^{\mathrm{bi}}$ & $37.20^{\mathrm{bi}}$ & $39.30^{\mathrm{bi}}$ & $36.40^{\mathrm{di}}$ & 0.69 \\
\hline & 5 & $36.80^{\mathrm{bj}}$ & $36.60^{\mathrm{bij}}$ & $38.60^{\mathrm{bij}}$ & $44.00^{\mathrm{ci}}$ & 0.77 \\
\hline & 10 & $39.10^{\mathrm{bj}}$ & $48.30^{\mathrm{ai}}$ & $41.60^{\mathrm{bj}}$ & $48.50^{\text {bci }}$ & 1.37 \\
\hline & 15 & $47.00^{\mathrm{ajk}}$ & $52.80^{\mathrm{aj}}$ & $44.90^{\mathrm{abk}}$ & $51.40^{\mathrm{bi}}$ & 1.47 \\
\hline & 20 & $50.30^{\mathrm{ai}}$ & $52.70^{\mathrm{ai}}$ & $49.00^{\mathrm{ai}}$ & $63.80^{\mathrm{ai}}$ & 0.74 \\
\hline & SEM & 1.10 & 1.21 & 0.85 & 1.53 & \\
\hline \multirow[t]{6}{*}{ Albumen height } & 0 & $6.90^{\text {aij }}$ & $7.30^{\mathrm{ai}}$ & $6.70^{\mathrm{aij}}$ & $7.50^{\mathrm{ai}}$ & 0.19 \\
\hline & 5 & $6.00^{\mathrm{abj}}$ & $5.90^{\mathrm{bj}}$ & $5.30^{\mathrm{bj}}$ & $6.00^{\mathrm{bj}}$ & 0.22 \\
\hline & 10 & $4.00^{\mathrm{ck}}$ & $6.00^{\mathrm{bi}}$ & $4.90^{\mathrm{bjk}}$ & $5.90^{\mathrm{bij}}$ & 0.18 \\
\hline & 15 & $5.60^{\mathrm{bi}}$ & $6.20^{\mathrm{abi}}$ & $3.30^{\mathrm{cj}}$ & $4.40^{\mathrm{cj}}$ & 0.21 \\
\hline & 20 & $5.30^{\mathrm{bi}}$ & $5.60^{\mathrm{bi}}$ & $2.90^{\mathrm{cj}}$ & $3.30^{\mathrm{cj}}$ & 0.22 \\
\hline & SEM & 0.20 & 0.15 & 0.22 & 0.25 & \\
\hline \multirow[t]{6}{*}{ Albumen length } & 0 & $80.90^{\mathrm{ci}}$ & $80.70^{\mathrm{bi}}$ & $83.60^{\mathrm{ci}}$ & $88.90^{\mathrm{ci}}$ & 1.28 \\
\hline & 5 & $107.50^{\mathrm{ai}}$ & $97.40^{\mathrm{ai}}$ & $107.40^{\mathrm{bi}}$ & $82.40^{\mathrm{cj}}$ & 3.20 \\
\hline & 10 & $100.20^{\mathrm{abi}}$ & $95.00^{\mathrm{ai}}$ & $104.90^{\mathrm{bi}}$ & $93.90^{\text {bci }}$ & 1.14 \\
\hline & 15 & $93.70^{\mathrm{bcj}}$ & $91.10^{\mathrm{abj}}$ & $123.50^{\mathrm{ai}}$ & $135.50^{\mathrm{ai}}$ & 3.39 \\
\hline & 20 & $106.40^{\mathrm{abj}}$ & $103.30^{\mathrm{aj}}$ & $125.00^{\mathrm{ai}}$ & $103.30 \mathrm{bj}$ & 2.08 \\
\hline & SEM & 1.97 & 1.51 & 2.40 & 3.45 & \\
\hline \multirow[t]{6}{*}{ Albumen ratio } & 0 & $60.89^{\mathrm{bi}}$ & $59.22^{\mathrm{bi}}$ & $65.17^{\text {bci }}$ & $56.68^{\mathrm{ci}}$ & 1.06 \\
\hline & 5 & $60.57^{\mathrm{bi}}$ & $61.13_{\mathrm{bi}}$ & $59.42^{\text {cdi }}$ & $65.43^{\mathrm{ci}}$ & 0.84 \\
\hline & 10 & $51.03^{\mathrm{cj}}$ & $62.35^{\mathrm{bi}}$ & $53.17^{\mathrm{di}}$ & $57.51^{\mathrm{cij}}$ & 1.54 \\
\hline & 15 & $79.00^{\mathrm{ajk}}$ & $84.27^{\mathrm{aj}}$ & $72.25^{\mathrm{bk}}$ & $98.69^{\mathrm{ai}}$ & 2.21 \\
\hline & 20 & $66.86^{\mathrm{bj}}$ & $67.86^{\mathrm{bj}}$ & $81.62^{a i}$ & $79.93^{\text {bi }}$ & 1.41 \\
\hline & SEM & 1.74 & 1.47 & 1.75 & 2.56 & \\
\hline \multirow[t]{6}{*}{ Albumen index } & 0 & $8.58^{\mathrm{ai}}$ & $9.09^{\mathrm{ai}}$ & $8.19^{\mathrm{ai}}$ & $6.91^{\mathrm{bi}}$ & 0.30 \\
\hline & 5 & $5.75^{\mathrm{aj}}$ & $6.14^{\mathrm{aj}}$ & $4.97^{\mathrm{aj}}$ & $17.98^{\mathrm{ai}}$ & 2.37 \\
\hline & 10 & $4.00^{\mathrm{ai}}$ & $6.36^{\mathrm{ai}}$ & $4.71^{\mathrm{ai}}$ & $6.29^{\mathrm{bi}}$ & 0.22 \\
\hline & 15 & $5.68^{\mathrm{ai}}$ & $6.82^{\mathrm{ai}}$ & $2.69^{\mathrm{ai}}$ & $2.97^{\mathrm{bi}}$ & 0.30 \\
\hline & 20 & $5.40^{\mathrm{ai}}$ & $5.48^{\mathrm{ai}}$ & $2.32^{\mathrm{ai}}$ & $2.92^{\mathrm{bi}}$ & 0.25 \\
\hline & SEM & 0.29 & 0.24 & 0.34 & 1.93 & \\
\hline
\end{tabular}

${ }^{a}, b, c, d$ means with different superscripts on the same column differ significantly $(\mathrm{P}<0.05) ;{ }^{1, j, k, 1}$ means along the same row with different superscripts differ significantly $(\mathrm{P}<0.05) ; 0,5,10,15,20$ - Storage days; SEM - Standard Error of Mean.

very high temperature, the amount of water movement from the albumen to the yolk is high, which helped to increase yolk diameter (Brake et al., 1997; Sati et al., 2020).

The albumen weight was significantly $(\mathrm{p}<0.05)$ affected by storage days. As a result, the highest albumen weight losses were recorded for 15 and 20 days of storage in both storage temperatures. This loss of albumen weight happened due to loss of solvents from albumen, which may decrease the weight of the albumen in egg by increasing the weight of yolk. These results are inconsistent with Siyar et al. (2007); Tabidi (2011) who noted that the loss in albumen weight is attributed to loss of humidity from inside the egg due to evaporation. Increased albumen weight loss at room temperature than in refrigeration recorded at 28 days of storage may be due to the higher amount of water loss from the albumen to the yolk. Similar results were demonstrated by Tona et al. (2004); Akyurek and Okur (2009) that water loss from eggs may be influenced by 


\section{Effect of storage duration and temperature on external and internal egg quality}

Table 4: Interaction effect of storage days and temperature difference on fertile and nonfertile albumen internal characteristics

\begin{tabular}{|c|c|c|c|c|c|c|}
\hline \multirow[b]{2}{*}{ Parameter } & \multirow[b]{2}{*}{ Days } & \multicolumn{2}{|c|}{ Fertile Egg } & \multicolumn{2}{|c|}{ Non-Fertile Egg } & \multirow[b]{2}{*}{ SEM } \\
\hline & & $\begin{array}{c}\text { Room } \\
\text { Temperature }\end{array}$ & $\begin{array}{l}\text { Refrigerator } \\
\text { Temperature }\end{array}$ & $\begin{array}{c}\text { Room } \\
\text { Temperature }\end{array}$ & $\begin{array}{l}\text { Refrigerator } \\
\text { Temperature }\end{array}$ & \\
\hline \multirow[t]{6}{*}{ Yolk:Albumen } & 0 & $0.40^{\mathrm{ai}}$ & $0.41^{\mathrm{bi}}$ & $0.42^{\mathrm{bi}}$ & $0.43^{\mathrm{ai}}$ & 0.01 \\
\hline & 5 & $0.45 \mathrm{ai}$ & $0.42^{\text {bi }}$ & $0.44^{\mathrm{bi}}$ & $0.40^{\mathrm{ai}}$ & 0.01 \\
\hline & 10 & $0.46^{\mathrm{ajk}}$ & $0.53^{\mathrm{aij}}$ & $0.59^{\mathrm{ai}}$ & $0.39^{\mathrm{ak}}$ & 0.01 \\
\hline & 15 & $0.38^{\mathrm{ai}}$ & $0.34^{\mathrm{bij}}$ & $0.39^{\mathrm{bi}}$ & $0.28^{\mathrm{bj}}$ & 0.01 \\
\hline & 20 & $0.37^{\mathrm{ai}}$ & $0.35^{\mathrm{bi}}$ & $0.35^{\mathrm{bi}}$ & $0.36^{\mathrm{abi}}$ & 0.01 \\
\hline & SEM & 0.01 & 0.01 & 0.02 & 0.01 & \\
\hline \multirow[t]{6}{*}{ Haugh unit } & 0 & $81.15^{\mathrm{aij}}$ & $84.43^{\mathrm{ai}}$ & $80.98^{\mathrm{aij}}$ & $83.80^{\mathrm{ai}}$ & 1.88 \\
\hline & 5 & $75.12^{\mathrm{abij}}$ & $77.12^{\mathrm{abi}}$ & $68.71^{\mathrm{bj}}$ & $74.64^{\mathrm{abj}}$ & 1.26 \\
\hline & 10 & $71.02^{\mathrm{bi}}$ & $74.70^{\text {bcj }}$ & $59.15^{\mathrm{cj}}$ & $66.94^{\text {bij }}$ & 2.21 \\
\hline & 15 & $67.57^{\mathrm{bi}}$ & $69.78^{\text {bci }}$ & $47.68^{\mathrm{dj}}$ & $54.86^{\mathrm{cj}}$ & 1.33 \\
\hline & 20 & $49.58^{\mathrm{ck}}$ & $66.90^{\mathrm{ci}}$ & $43.81^{\mathrm{dj}}$ & $42.45^{\mathrm{dj}}$ & 2.45 \\
\hline & SEM & 1.88 & 1.26 & 2.21 & 2.34 & \\
\hline \multirow{6}{*}{ Egg surface area } & 0 & $507.90^{\text {bi }}$ & $501.50^{\mathrm{bi}}$ & $483.87^{\mathrm{bi}}$ & $519.12^{\text {bi }}$ & 10.15 \\
\hline & 5 & $487.08^{\mathrm{bj}}$ & $505.50^{\mathrm{bij}}$ & $519.92^{\text {baj }}$ & $544.75^{\text {bi }}$ & 11.10 \\
\hline & 10 & $613.65^{\mathrm{aj}}$ & $621.66^{\mathrm{aj}}$ & $628.07^{\text {aij }}$ & $672.72^{\text {bi }}$ & 10.15 \\
\hline & 15 & $479.07^{\mathrm{bi}}$ & $502.30^{\text {bi }}$ & $500.69^{\text {bi }}$ & $520.72^{\text {bi }}$ & 9.13 \\
\hline & 20 & $603.24^{\mathrm{ai}}$ & $621.66^{\mathrm{ai}}$ & $483.07^{b j}$ & $515.92^{\mathrm{bj}}$ & 10.11 \\
\hline & SEM & 10.15 & 10.15 & 9.16 & 10.11 & \\
\hline \multirow[t]{6}{*}{ Shape index } & 0 & 78.95 & 77.86 & 78.13 & 78.05 & 0.48 \\
\hline & 5 & 81.59 & 77.93 & 70.93 & 76.22 & 1.25 \\
\hline & 10 & 81.57 & 72.46 & 77.07 & 76.5 & 1.05 \\
\hline & 15 & 75.59 & 77.4 & 75.24 & 80.13 & 1.70 \\
\hline & 20 & 79.37 & 80.14 & 82.56 & 78.96 & 0.76 \\
\hline & SEM & 1.15 & 0.87 & 0.81 & 1.17 & \\
\hline
\end{tabular}

a, b,c, d means with different superscripts on the same column differ significantly $(\mathrm{P}<0.05) ;, \mathrm{l}, \mathrm{j}, \mathrm{l}, \mathrm{l}$ means along the same row with different superscripts differ significantly $(\mathrm{P}<0.05) ; 0,5,10,15,20$ - Storage days; SEM - Standard Error of Mean

storage time, temperature, relative humidity and porosity of the shell.

Haugh Unit (HU) of fresh eggs declined significantly $(\mathrm{P}<0.05)$ with increasing storage days. Reduction in HU was due to the decrease in thick albumen height, because during storage, the ovomucinlysozyme complex breaks down, which helps to increase the $\mathrm{pH}$ of eggs. This finding was consistent with Morais et al. (1997) who observed reduced Haugh Unit of eggs at 21 days of storage. In addition, storage temperatures can affect the HU of eggs. High storage temperatures encourage the breakdown of ovomucin-lysozyme complex. As a result, Haugh Unit of eggs stored at room temperature was decreased compared to refrigeration. The results are in agreement with (Campos et al., 1975; Sauveur, 1993; Samli et al., 2005; Sati et al., 2020) that storage days and temperature adversely affects HU of eggs. Accordingly, other researchers like (Tona et al., 2004; Akyurek et al., 2009; Sati et al., 2020) reported that the rate of water loss from egg is influenced by the rate of evaporation from egg content.

Shape index was not affected significantly $(\mathrm{P}>0.05)$ by storage days and temperature. These results are also in line with (Woodard, 1982; Song et al., 2000; Tilki and Saatci, 2004) who observed no effect of storage days and temperature on shape index of eggs. The results obtained between fertile and non-fertile eggs colour was significantly different $(\mathrm{p}<0.05)$. The 
Oshibanjo, Sati, Emennaa, Okpanchi, Nwamo, Mbuka, Njam, Mwadkon, Ejidare, Kaze. and Ene

Table 5: Interaction effect of storage days and temperature difference on sensory evaluation of fertile and non-fertile eggs

\begin{tabular}{|c|c|c|c|c|c|c|}
\hline \multirow[b]{2}{*}{ Parameter } & \multirow[b]{2}{*}{ Days } & \multicolumn{2}{|c|}{ Fertile Egg } & \multicolumn{2}{|c|}{ Non-Fertile Egg } & \multirow[b]{2}{*}{ SEM } \\
\hline & & $\begin{array}{c}\text { Room } \\
\text { Temperature }\end{array}$ & $\begin{array}{l}\text { Refrigerator } \\
\text { Temperature }\end{array}$ & $\begin{array}{c}\text { Room } \\
\text { Temperature }\end{array}$ & $\begin{array}{l}\text { Refrigerator } \\
\text { Temperature }\end{array}$ & \\
\hline \multirow[t]{6}{*}{ Colour } & 0 & $2.00^{\mathrm{abi}}$ & $2.00^{\mathrm{bi}}$ & $1.33^{\mathrm{bi}}$ & $1.33^{\mathrm{ai}}$ & 0.48 \\
\hline & 5 & $1.5^{\mathrm{bi}}$ & $1.50^{\mathrm{bi}}$ & $2.50^{\mathrm{bi}}$ & $2.83^{\text {abi }}$ & 0.48 \\
\hline & 10 & $2.83^{\mathrm{ai}}$ & $3.50^{\mathrm{ai}}$ & $3.67^{\mathrm{aij}}$ & $4.50^{\mathrm{ai}}$ & 0.42 \\
\hline & 15 & $2.22^{\mathrm{abj}}$ & $2.56^{\mathrm{aij}}$ & $2.67^{\text {abij }}$ & $1.56^{\mathrm{ai}}$ & 0.31 \\
\hline & 20 & $2.67^{a b i}$ & $3.42^{\mathrm{ai}}$ & $2.00^{\mathrm{ai}}$ & $3.58^{\mathrm{ai}}$ & 0.19 \\
\hline & SEM & 0.32 & 0.42 & 0.35 & 0.35 & \\
\hline \multirow[t]{6}{*}{ Odour } & 0 & 2.00 & 2.00 & 1.33 & 1.33 & 0.10 \\
\hline & 5 & 1.50 & 1.50 & 2.50 & 2.83 & 0.30 \\
\hline & 10 & 2.83 & 3.50 & 3.67 & 4.50 & 0.30 \\
\hline & 15 & 2.22 & 2.56 & 2.67 & 1.56 & 0.28 \\
\hline & 20 & 2.67 & 3.42 & 2.00 & 3.58 & 0.31 \\
\hline & SEM & 0.23 & 0.29 & 0.29 & 0.38 & \\
\hline \multirow[t]{6}{*}{ Aroma } & 0 & 4.00 & 4.00 & 4.00 & 4.00 & 0.10 \\
\hline & 5 & 3.67 & 3.17 & 3.67 & 3.00 & 0.30 \\
\hline & 10 & 4.17 & 4.33 & 3.67 & 4.83 & 0.30 \\
\hline & 15 & 4.11 & 3.67 & 3.56 & 4.00 & 0.28 \\
\hline & 20 & 4.67 & 4.25 & 3.92 & 4.08 & 0.31 \\
\hline & SEM & 0.21 & 0.22 & 0.20 & 0.25 & \\
\hline \multirow[t]{6}{*}{ Taste } & 0 & 6.67 & 6.67 & 6.00 & 6.00 & 0.00 \\
\hline & 5 & 4.83 & 6.33 & 4.83 & 5.83 & 0.26 \\
\hline & 10 & 6.17 & 6.33 & 6.33 & 6.17 & 0.27 \\
\hline & 15 & 6.11 & 5.56 & 5.00 & 6.44 & 0.26 \\
\hline & 20 & 6.08 & 6.33 & 6.83 & 6.33 & 0.26 \\
\hline & SEM & 0.66 & 0.21 & 0.28 & 0.21 & \\
\hline \multirow[t]{6}{*}{ Texture } & 0 & $6.17^{\mathrm{ai}}$ & $6.17^{\mathrm{ai}}$ & $4.83^{\mathrm{ai}}$ & $4.83^{\mathrm{ai}}$ & 0.20 \\
\hline & 5 & $5.50^{\mathrm{ai}}$ & $4.67^{\mathrm{ai}}$ & $6.50^{\mathrm{ai}}$ & $4.70^{\mathrm{ai}}$ & 0.33 \\
\hline & 10 & $6.89^{\mathrm{ai}}$ & $6.67^{\mathrm{ai}}$ & $6.67^{\mathrm{ai}}$ & $6.00^{\mathrm{ai}}$ & 0.26 \\
\hline & 15 & $6.89^{\mathrm{ai}}$ & $5.89^{\mathrm{aij}}$ & $4.67^{\mathrm{aj}}$ & $5.11^{\mathrm{aij}}$ & 0.35 \\
\hline & 20 & $4.83^{\mathrm{ai}}$ & $4.83^{\mathrm{ai}}$ & $5.58^{\mathrm{ai}}$ & $6.17^{\mathrm{ai}}$ & 0.30 \\
\hline & SEM & 0.27 & 0.28 & 0.29 & 0.25 & \\
\hline Overall & 0 & 5.83 & 5.83 & 6.83 & 6.83 & 0.15 \\
\hline \multirow[t]{5}{*}{ acceptability } & 5 & 7.00 & 7.67 & 5.5 & 6.33 & 0.35 \\
\hline & 10 & 8.00 & 7.33 & 6.83 & 6.17 & 0.31 \\
\hline & 15 & 7.67 & 7.00 & 7.56 & 7.44 & 0.26 \\
\hline & 20 & 6.08 & 6.83 & 7.00 & 6.75 & 0.27 \\
\hline & SEM & 0.30 & 0.26 & 0.27 & 0.23 & \\
\hline
\end{tabular}

$a, b, c, d$ means with different superscripts on the same column differ significantly $(\mathrm{P}<0.05)^{\mathrm{I}, \mathrm{j}, \mathrm{k}, \mathrm{l}}$ means

along the same row with different superscripts differ significantly $(\mathrm{P}<0.05) \quad 0,5,10,15,20$ - Storage

days; SEM - Standard Error of Mean.

highest colour was recorded for non-fertile egg stored under room temperature, which the least colour was observed on fertile egg stored under room temperature. The result obtained for colour could be due to fertilization process and moisture content losses that occurs during storage.

\section{Conclusion}

Interaction between storage days and temperature revealed that fertile eggs could be stored in refrigerator at $10^{\circ} \mathrm{C}$ for 10 days while non-fertile eggs could be stored in room temperature at $28-31^{\circ} \mathrm{C}$ for 10 days without adverse effect on the egg quality 1 and sensory evaluation. 


\section{References}

Akyurek, H. and Okur, A. A. 2009. Effect of storage time, temperature and hen age on egg quality in freerange layer hens. Journal of Animal and Veterinary Advances 8:1953-1958

Bell, D. 1996. Effects of temperature and storage time on egg weight loss. Poultry International $\mathbf{3 5}$ (14):56-64.

Brake, J., Walsh, T. J., Benton, C. E., Petitte Jr., J. N., Meijerhof, R. and Penalva, G. 1997. Egg handling and storage. Poultry Science 76 (1):144-151.

Campos, E. J. and Baião, N. C. 1975. Efeitos da temperatura, período e p o s i ção d u ra n t e o armazenamento sobre a qualidade interna de ovos de consumo. Congresso Brasileiro de avicultura, 4, Porto Alegre. Anais, Porto Alegre, pp. 179182.

Fasina, D. E., Oke, M. O., and Oke, D. B. 2012. Influence of different storage conditions on cholesterol content of domestic fowl egg. ASAN-NIAS Proceedings.

Food and Health Organization, FAO Corporate Document Repository (FAO- CDR) 2003. Egg marketing- Marketing Quality Eggs. Chapter Two. Agriculture and consumer protection. Available at http://www.fao.org/docrep/005/y 4628e/y4628e04.html. Retrieved on $20 / 09 / 19$

Haruna, U., Daneji M. I. and Idi, S. 2007. Comparative Economic Analysis of Adopters and $\quad N o n$ adopters in Bauchi LGA, Bauchi State. Proceedings of the 8th Annual $\quad \mathrm{C}$ on f e r e n c e Nigerian Society for Animal
Production, AESON, pp: 55-62.

Jibir, M., Garba, S. ans Ribah, M. I. 2012.

Relative importance of external Quality Attributes of shell eggs. A consumer preference approach. International Journal of Applied Agriculture and Apicultural Research 8 (1): 3138.

Joseph, J. K. and Ogundele, O. G. 1996. Shelf life of hen's egg as

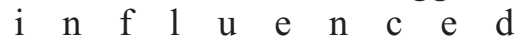
by coating with shear butter fat, palm kernel oil and film

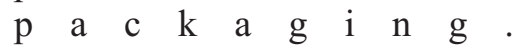
Nigerian Journal of Pure and Applied Science 11:398-404.

Leeson S. 2006. Defining and predicting changes in nutrient requirements of poultry. World Poultry Sci. J. 62 ,

Kabir, M.O., Sulaiman, R.O. and Idris, R. K. 2013. Effects of strain, age and the interrelationships between external and internal qualities of eggs between two strains of layer chickens in Northern Guinea S avannah Zone of Nigeria. Iranian Journal of Applied Animal Science. 4(1): 179-184.

Kirunda, D. F. K. and McKee, S. R. 2000. Relating quality characteristics of aged eggs and fresh eggs to vitelline membrane strength as determined by a texture analyzer. Poultry Science. 79(8):11891193.

Mohammed, H.T. 2011. Impact of Storage Period and Quality on Composition of Table egg. Advances in Environmental Biology 5(5): 856-861.

Morais, C. F. A., Campos, E. J. and Silva, T. J. P. 1997. Qualidade interna de ovos comercializados em diferentes supermercados na 
cidade de Uberlândia. Arquivo Brasileiro de Medicina Veterinária e Zootecnia 49:365373.

National Egg Coordination Committee, NECC, 2014. Food and Egg Nutrition. Available at http://www.e2necc. Com/egg -index html. Retrieved 20/09/19.

Obi and Igbokwe, A. J. 2009. Microbial Analyses of freshly laid and stored domestic poultry eggs in selected poultry farms in Umuahia, Abia. Nigeria. Research Journal of Biological Sciences. 4(12): 1297-1303.

Okeudo. N. J., Ezetoha, U., Akomas, C. and Akanno, E. C. 2005. Egg quality of Gallus Domesticus under domestic storage in Nigeria. Animal Resesrch International 2(2): 391-321.

Raji, A. O., Aliyo, J., Igwubuike, J. U. and Chiroma, S. 2009. Effect of Storage Methods and time on Egg Quality storage traits of laying hens in hot dry climate. Asian Research Publishing Network. Journal of Agricultural and Biological Science 4:4.

Samli, H. E., Agna, A. and Senkoylu, N. 2005. Effects of storage time and temperature on egg quality in old laying hens. Journal of A $p$ p 1 i $\quad$ e $d$ Poultry Research 14:548-533

Sati, N. M., Oshibanjo, D. O., Emennaa, P. E., Mbuka, J. J., Haliru, H., Ponfa, S. B., Abimiku, O. R., \& Nwamo, A. C. (2020). Egg Quality Assessment within Day 0 to 10 as Affected by Storage Temperature. Asian Journal of Research in Animal and Veterinary Sciences, 6(3), 15-25. $\mathrm{R}$ e $\mathrm{t} \mathrm{r} \mathrm{i}$ e $\mathrm{v}$ e d f $\mathrm{r}$ o $\mathrm{m}$ https://www.journalajravs.com/i
ndex.php/AJRAVS/article/view/ 30114

Sauveur, B. E. 1993. lhuevo para consumo: Bases productivas. Tradução por Carlos Buxadé Carbó. Aedos Editorial, Barcelona, $377 \mathrm{p}$.

Scotts, T. A. and Silversides, F. G. 2000. The Effect of Storage and Strains of Hen on Egg Quality. Poultry Sciences and Technology 79: 1725-1729.

Siyar, H. S. A., Aliarabi, H., Ahmadi, A. and Ashori, N. 2007. Effect of different storage conditions and hen age on egg quality parameters. Australia Poultry Science Symposium 19:106-109.

Song, K. T., Choi, S. H. and Oh, H. R. 2000. A comparism of egg quality of pheasant, chukar, quail and guinea fowl. AsianAustralian Journal of Animal Science 7:986-990.

Stadelman, W. J. 1995. Quality identification shell egg. In $\mathrm{S} \mathrm{t}$ a $\mathrm{d}$ e $\mathrm{m}$ a $\mathrm{n}$, W.J. and Cotterill, O.J. (eds). Egg Science and Technology. 4th edn. The Haworth Press, Inc., New York, London, pp. 39-66.

Stadelman, W. J and Coterill, O. J. 1986. The preservation of quality of Shell eggs. In: Stadelmann and Coterill O.J. (eds). Egg Science and Technology. Avi Publishing c o m., In c, We s t P ort, Connecticut, USA. United States of Department of AgricultureAgriculture Marketing Service, USDA-AMS (2000): Egg grading manual. Agricultural Marketing Division. Agricultural Handbook NO.75, U.S. Department of Washington D.C.

Tabidi, M. H. 2011. Impact of storage period and quality on 
composition of table egg. Advanced Environmental Biology 5(5):856-861.

Tilki, M. and Saatci, M. 2004. Effects of storage time on external and internal characteristics in partridge (Alectoris graeca) eggs. Revue Medicine Veterinary 155(11):561-56.

Tona, K., Onagbesan, O., De Ketelaere, B. and Decuypere, E. and Bruggeman, V. 2004. Effects of age of broiler breeders and egg storage on egg quality, hatchability chick quality, chick weight and chick post hatch growth to 42 days. Journal of Applied Poultry Research 13(1):10-18.

United States of Department of Agriculture- Food Safety and Inspection Service, USDAFSIS 2011. Shell Eggs from Farm to Table. Available at http://www.fsis.usda.gov/factshe ets/focus on shell eggs/index.asp. Last modified 2011. Archived (1995-2003).
Woodard, A. E. 1982. Raising Chukar Partridge. Department of Avian Sciences, University of California, Davis, CA 95616. A v a i 1 a b 1 e : http://animalscience.ucdavis.ed u/avian/chukar.pdf. Accessed on 20/09/19.

Zeidler, G. 2002. Shell quality and preservation. In Bell, D. D. \& W e a $v$ e r , W. D. Jr. (eds). Commercial Chicken Meat and Egg Production. $5 \mathrm{th}$ rev. edn. Kluwer Academic Publishers, Norwell, pp. 11991217.

Received: $14^{\text {th }}$ October, 2020 Accepted: $10^{\text {th }}$ February, 2021 